${ }^{*}$ RMIS View/Frint Document Cover Sheet tok

This document was retrieved from the Documentation and Records Manaqement (DRM) ISEARCH System. It is intended for Information only and may not be the most recent or updated version. Contact a Document Service Center (see Hanford Info for locations) if you need additional retrieval information.

Accession \#: D196046294

Document \#: SD-SNF-ER-011

Title/Desc:

TECHNICAL ISSUE MGMT BOARD DECISION MEMORANDUM NO 3 FUEL SORTING

Pages: 30 


\begin{tabular}{|l|l|}
\hline $\begin{array}{l}\text { 2. To: (Receiving Organization) } \\
\text { Spent Nuclear Fuel Project }\end{array}$ & $\begin{array}{l}\text { 3. From: (Orisinating Organization) } \\
\text { Technical Issue Management } \\
\text { Board }\end{array}$ \\
\hline $\begin{array}{l}\text { 5. Proj./Prog./Dept./Div.: } \\
\text { Spent Nuclear Fuel Project }\end{array}$ & $\begin{array}{l}\text { 6. Cog. Engr.: } \\
\text { GE Culley }\end{array}$ \\
\hline
\end{tabular}

8. Originator Remarks:

Approval of this EDT by the Technical Issue Managenent Board members establishes formal resolution and closure of the Fuel Sorting issue. The Board's decision as described in the Decision Menorandum is to be implenented throughout the Spent Nuclear fuel Project.

11. Receiver Remarks:
4. Related EDT No.:

$N / A$

7. Purchase order No.: $N / A$

9. Equip./Component No.: $N / A$

10. Systen/Bldg./Facility: $N / A$

12. Major Assm. Dug. No.: $N / A$

13. Permit/Permit Application No.: $\mathrm{N} / \mathrm{A}$

14. Required Response Date: $N / A$

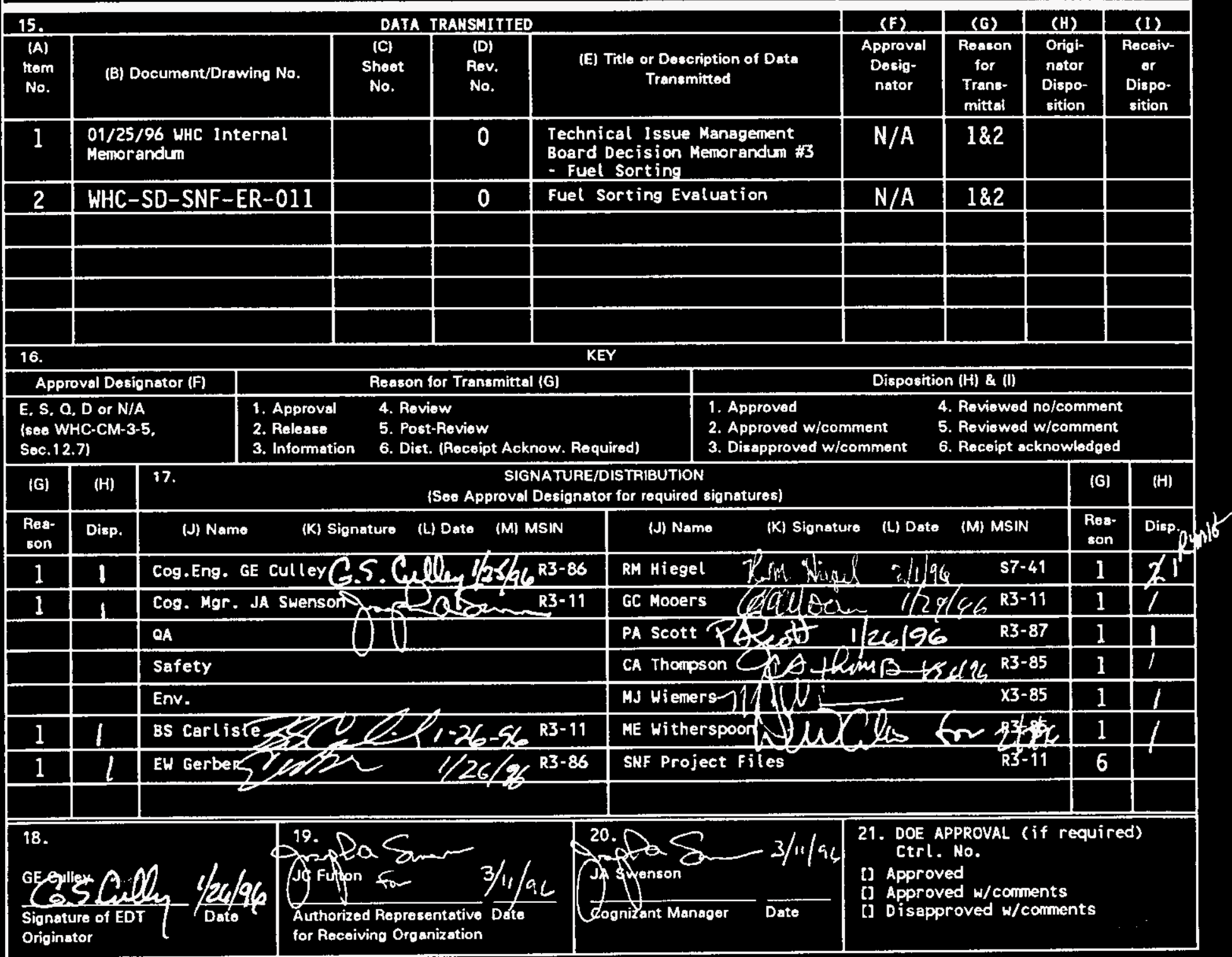

BD-7400-172-2 (04/94) GEF097 


\title{
Fuel Sorting Evaluation
}

\author{
AL Pajunen \\ Westinghouse Hanford Company, Richland, WA 99352 \\ U.S. Department of Energy Contract DE-AC06-87RL10930

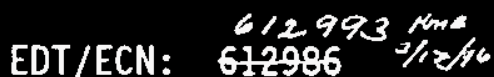 \\ Org Code: 2C400 \\ UC: UC-510 \\ B\&R Code: EW3135040 Total Pages: $3326 \mathrm{knd} \$ / \mathrm{m} / \mathrm{s} / \mathrm{A}$
}

Key Words: Fuel, Sorting, Spent Nuclear Fuel

Abstract: An evaluation of functions and requirements associated with sorting fuel from the Hanford $\mathrm{K}$ Basins is presented to support design issue resolution decisions for achieving interim fuel storage.

Potential requirements satisfed by fuel sorting are identified and a subset of these requirements are recommended for implementation in design activities. The recommendations are provided as input to a management decision process where decisions are finalized and the sorting issue is closed.

TRADEMARK DISCLAIMER. Reference herein to any specific comnercial product, process, or service by trade name, tradenark, manufacturer, or otherwise, does not necessarily constitute or imply its endorsenent, recommendation, or favoring by the United States Government or any agency thereof or its contractors or subcontractors.

Printed in the United States of America. To obtain copies of this document, contact: WHC/BCS Document Control Services, P.O. Box 1970, Mailstop H6-08, Richland HA 99352 , Phone (509) 372-2420. Fax (509) 376-4989.
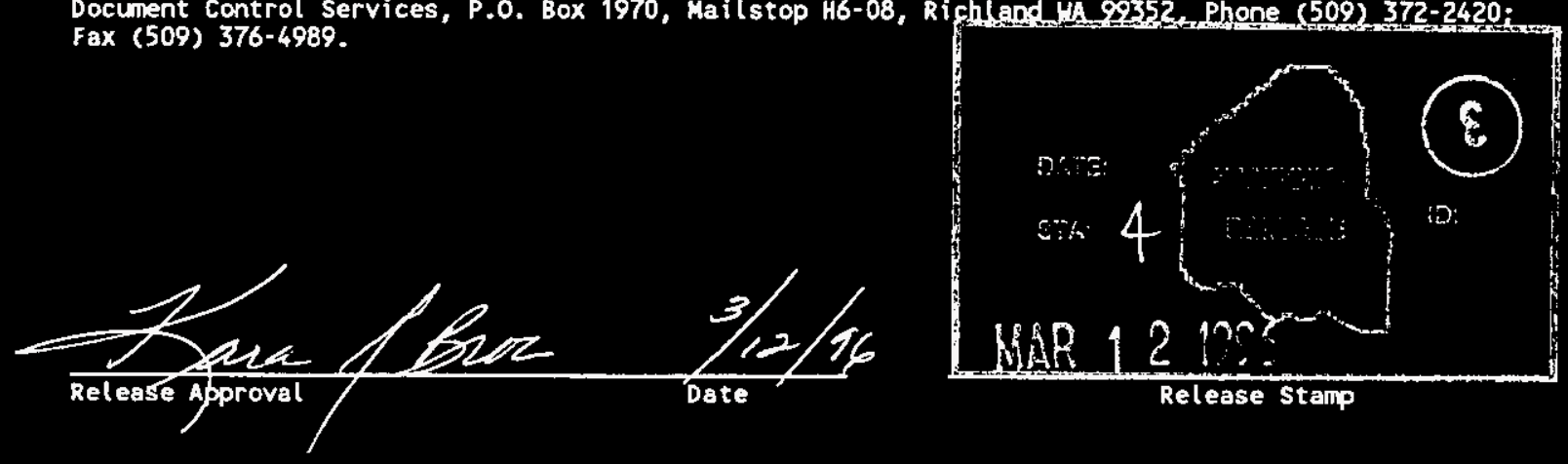

Approved for Public Release 


\author{
WHC-SD-SNF-ER-011, Rev 0
}

FUEL SORTING EVALUATION

\title{
EXECUTIVE SUMMARY
}

The following fuel sorting evaluation was completed to recommend fuel sorting functions and requirements incorporated into the Spent Nuclear Fuel Project. The evaluation supports resolution of Issue 168 in the Technical Issues Management Database. Based on the current design concepts, fuel sorting during fuel retrieval from the basins is the final opportunity to adjust the attributes of fuel combined in a Multi Canister Overpack (MCO). Therefore, the sorting evaluation considered the potential for requirements to be imposed by each SNFP Sub-Project interfacing with a loaded MCO. The result is identification of all known sorting requirements for the SNFP.

The sorting evaluation was initiated by assembling a task team with members representing sub-projects interfacing with a loaded MCO. These interfacing sub-projects included Fuel Retrieval, Multi Canister Overpack, Cask and Transportation, K Basin Vacuum Drying, Canister Storage Building, Conditioning, and General Areas which cross cut sub-projects (e.g., criticality, accountability, etc.). Potential fuel sorting requirements were compiled from each sub-project and reviewed by the task team. The task team review determined if,

- fuel sorting had a primary influence on satisfying the potential requirement (if not, dropped from further consideration as a sorting requirement),

- an alternative to fuel sorting was available for satisfying the potential requirement, or

- fuel sorting was the only method for satisfying the potential requirement.

Schedule requirements for the Spent Nuclear Fuel Project require that a recommendation on fuel sorting be provided based on incomplete data. The recommendations which follow, if accepted, allows the project to proceed at risk. It was assumed that minimal fuel sorting requirements should be specified to minimize the potential for increasing operator dose and operational error. Therefore, only requirements which could not be satisfied by alternatives to sorting are included in the recommendation. However, limiting fuel sorting in this manner implies accepting that an alternative to fuel sorting, where available, will be pursued to satisfy some project requirements. 
WHC-SD-SNF-ER-011, Rev 0

The evaluation results recommend including a fuel sorting function in the fuel retrieval systems. The recommended requirements satisfied by the fue] sorting function are as follows:

- Mk 1A fuel must be placed in the baskets designed with a larger central void for criticality control (this requirement does not preclude the option of placing some shorter Mk IV elements in baskets with Mk $1 \mathrm{~A}$ elements),

- Single Pass Reactor (SPR) fuel should be placed in shorter fuel baskets and possibly loaded separately into $M C O(s)$ to allow segregated

processing of SPR fuel, and

- Element sorting to differentiate elements included in the MCo inventory by piece count data from elements inventoried by weight.

Additional sorting factors were identified with the potential to become sorting requirements in the future. These factors, requiring additional study prior to defining as a requirement, are as follows:

- Sorting to direct partial elements to a scrapholder or fuel basket such that efficient utilization of a MCO is achieved, and

- Element sorting to ensure fuel baskets are loaded with elements which approach the geometries analyzed by the criticality analys is.

It is recommended that other potential sorting requirements associated with narrowing the variability of heat generation rates produced by MCOs and reducing the number of MCOs which may need conditioning not be included as a fuel sorting requirement at this time.

Data are not available to specify if some of the identified sorting factors should be included as system design requirements. The following additional studies are recommended to provide for detailed definition.

- Development of a definition for an intact element to determine if piece count data or weighing is used for accountability,

- Development of a scrapholder design concept followed by a trade study defining the partial element length which should be placed in a scrapholder for efficient MCO utilization,

- Completion of documenting currently available criticality analyses,

- Development of a practical definition for fuel geometries which comply with the MCO criticality analys is bounding conditions 


\section{WHC-SD-SNF-ER-011, Rev 0 \\ TABLE OF CONTENTS}

EXECUTIVE SUHMARY .................... i

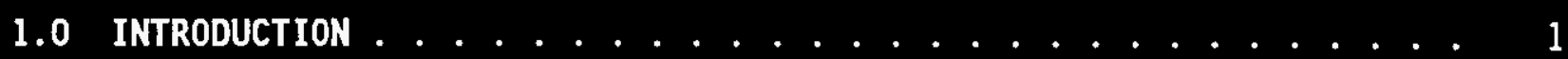

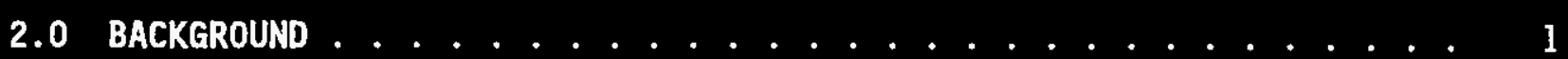

3.0 FUEL SORTING EVALUATION ................. 3

3.1 EVALUATION METHODOLOGY . . . . . . . . . . . . 4

3.2 DISCUSSION .......................... 4

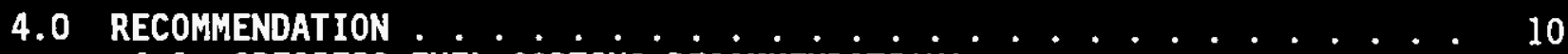

4.1 SPECIFIC FUEL SORTING RECONMENDATIONS $\cdots \cdots$

4.2 RECOMMENDED ADDITIONAL STUDIES . . . . ........ 13

5.0 REFERENCES . . . . . . . . . . . . . 15

6.0 ACKNOHLEDGEMENT . . . . . . . . . . . . . . . . 16

Appendix A

Summary of Potential Requirements Considered

for Influence by Fuel Sorting . . . . . . . . . . . . . . . 17

\section{LIST OF TABLES}

Table 1. Identified Requirements Needing Fuel Element

or Fuel Canister Sort to Satisfy ... . . . . . . . . . . 5 Table 2. Identified Requirements Satisfied by Alternatives to Sorting . 6 
WHC-SD-SNF-ER-011, Rev 0

FUEL SORTING EVALUATION

\subsection{INTRODUCTION}

This report was prepared to support resolution of Issue 168 in the Technical Issues Management Database for the Spent Nuclear Fuels Project (SNFP). The purpose of this document is to identify if fuel sorting is needed and recommend an approach for sorting the Spent Nuclear Fuel (SNF) in the $K$ Basins based on potential requirements identified to support the fuel retrieval through interim storage systems of the SNFP. The scope of the evaluation included consideration of process elements with in the Fuel Retrieval, Multi-Canister Overpack, Vacuum Drying, Canister Storage Building, and Conditioning Sub-Projects which may require implementation of a fuel sorting scheme to successfully support the interim storage of fuel from the $K$ Basins. The evaluation will identify requirements potentially influenced by fuel sorting, identify fuel sorting criteria which would satisfy those requirements, identify and evaluate the potential for alternatives to satisfy those same requirements, and develop an overall recommendation for fuel sorting criteria which should be implemented in design efforts. The result is the identification of all currently known sorting requirements for the SNFP.

\subsection{BACKGROUND}

The $K$ East (KE) and $K$ West (KW) Basins store SNF in three types of canisters (Marks 0, I, and II). There are 3666 canisters containing 50,683 fuel assemblies in KE Basin and 3815 canisters containing 52,959 fuel assemblies in KW Basin (WHC 1995a). KW Basin contains four types of fuel (N Reactor fuel types Mk IA, Mk IV, Mk IVB, and Single Pass Reactor (SPR) fue1), while KE Basin contains three fuel types (N Reactor fuel types Mk IV, Mk IVB, and SPR fuel). The SPR fuel can be visually distinguished from the N Reactor fuel types based on distinctive design differences. However, $N$ Reactor fuel types are sufficiently similar in appearance (element inside and outside diameter differences range from 0.05 to $0.18 \mathrm{~cm}$ ) to preclude distinction using visual observation alone. Identification of the Mk $1 \mathrm{~A}$ fuel type can have implications in the development of designs which must maintain criticality controls, as the Mk $1 \mathrm{~A}$ outer element was fabricated from uranium with an enrichment of $1.25 \mathrm{Wt} \%{ }^{235} \mathrm{U}$, while the inner element contains $0.947 \mathrm{Wt} \%{ }^{235} \mathrm{U}$. Mk IV and Mk IVB assemblies contain inner and outer fuel elements fabricated from uranium enrichments of less than or equal to $0.947 \mathrm{Wt} \%{ }^{235} \mathrm{U}$.

A variety of $\mathrm{N}$ Reactor fuel element lengths were produced and are stored in the $\mathrm{K}$ Basins. Mk IV fuel element lengths range from $44.2 \mathrm{~cm}$ to $66.3 \mathrm{~cm}$ while Mk $1 \mathrm{~A}$ element lengths range from $37.8 \mathrm{~cm}$ to $53.1 \mathrm{~cm}$ (WHC 1995a). Therefore, length could be considered as an attribute for differentiating between Mk $1 \mathrm{~A}$ and most of the Mk IV fuel. 


\section{WHC-SD-SNF-ER-011, Rev 0}

$\mathrm{N}$ Reactor fuel within each fuel type has been subjected to exposures ranging from 0 to 3600 MWD/MTU and discharged over a 16 year period (January 1971 to April 1987) creating fuel with a range of radionuclide compositions (WHC 1995a). This radionuclide composition range also translates into a variation in the heat generation rate from groups of fuel elements within each fuel type.

SPR fuel is currently stored in both basins. The length of SPR fuel elements range from approximately $12 \mathrm{~cm}$ to $23 \mathrm{~cm}$, with specific lengths generally associated with enrichment ranges. The element diameters range from approximately $3.45 \mathrm{~cm}$ to $3.63 \mathrm{~cm}$ (WHC 1995a).

There are 3.38 MTHM of SPR fuel at Hanford. The majority of SPR fuel is 2.88 MT of highly depleted uranium contained in 779 fuel elements which have recently been transferred from PUREX to the KW Basin. The remaining 0.5 MT of SPR fuel is natural or enriched uranium contained in 185 elements located in $\mathrm{KE}(0.4 \mathrm{MT}$ in 138 elements) and $\mathrm{KW}(0.1 \mathrm{MT}$ in 47 elements) Basins. The KE Basin fuel is currently stored in 3 canisters and 2 baskets. The transfer of SPR fuel to canisters in KW Basin was incomplete at the time this report was prepared. However, it is estimated SPR fuel will be stored in approximately 22 canisters in KW Basin when the transfer is complete.

The physical condition of stored fuel elements also varies within the basins. Some of the stored fuel elements have cladding breaches which allows the initiation of corrosion reactions between the uranium metal core and the storage basin water. The reactions potentially produce corrosion products with in the fuel element cladding or adhering to the fuel surface which can interfere with processes transferring fuel to dry interim storage. An underwater visual survey of fuel in the KE Basin was conducted in 1994 as part of fuel characterization activities. The visual survey concluded that over $90 \%$ of the loaded canisters in KE Basin contain at least one breached fuel element. It was further estimated that approximately $27 \%$ of all inner elements and $42 \%$ of al1 outer elements stored in KE Bas in are breached to some extent (WHC 1995a). The extent of fuel reaction varies within the KE Basin fuel elements, ranging from a break or opening in the cladding-to-end cap braze area to reactions sufficient to swell fuel and split cladding. Void spaces within the cladding where a significant portion of the uranium fuel core has been removed can be observed for some elements. Extensive visual survey data of $\mathrm{KW}$ Basin fuel is not available. Each storage canister includes a lid for isolation of the fuel from the basin water preventing simple visual surveys. However, selected canisters (three) have been opened to obtain fuel samples as part of characterization activities. Observations from this limited number of canisters suggest fuel corrosion in the KW Bas in should not be expected to be as extensive as that observed in the KE Basin visual survey.

The variations described above indicate potential fuel sorting schemes could be proposed to group fuel based on a number of different attributes. The Integrated Process Strategy (WHC 1995b) transfers fuel from the basins to dry interim storage based on placing fuel in a Multi-Canister overpack (MCO) at the basins. No allocation has been made to routinely reopen the $M C O$ and 


$$
\text { WHC-SD-SNF-ER-011, Rev } 0
$$

redistribute fuel once it is placed in an MCO and the shield plug welded in place. Fuel sorting during the fuel retrieval activities in the basins is the final opportunity to adjust the attributes of fuel combined to be packaged in an MCO. Therefore, an evaluation of fuel sorting must consider the potential requirements for each SNFP sub-project which interfaces with the loaded MCO. These sub-projects, as identified in WHC 1995c, are:

- Fuel Retrieval - performs any potential canister or fuel sorting activities and loads the MCO fuel baskets

- Multi-Canister Overpack - procures MCOs and welds shield plug on loaded MCO

- Cask and Transportation - procures MCO transport cask, moves loaded MCO from basin to vacuum drying, and transports loaded MCO from 100 Area to Canister Storage Building

- $\quad K$ Basin SNF Vacuum Drying - dries fuel in a loaded MCO to a condition allowing transport to and staging in the Canister Storage Building

- Canister Storage Building - provides staging and interim storage of a loaded MCO

- Conditioning - conditions fuel in a loaded MCO and seals the MCO allowing transfer from staging to interim storage.

\subsection{FUEL SORTING EVALUATION}

A definition of fuel sorting was established prior to development of a fuel sorting evaluation. Two general types of sorting are available with in the $\mathrm{K}$ Basins based on the fuel storage configuration. These alternatives are:

- Fuel Element Sorting - This type of sorting is based on examining or measuring each element for some attribute which forms the basis for directing the element to a subsequent processing path.

- Fuel Canister Sorting - This type of sorting is possible by relying on the safeguards accountability records to identify location and characteristics of fuel keys (groups of fuel elements discharged on the same day), selecting the fuel from groups of canisters, and placing fue? in a single MCO to achieve a desired product characteristic. The product characteristic in this case would be calculated from the fuel records data and confirmed on an individual MCO basis rather than examining each fuel element.

A third type of physical sort is possible from the system configuration and that is by fuel basin. However, the process systems under consideration 
WHC-SD-SNF-ER-011, Rev 0

will naturally maintain KE Basin fuel sorted from KW Basin fuel. Therefore, unless a need is identified to mix fuel from separate basins, sorting by basin will be assumed throughout the evaluation which follows.

\subsection{EVALUATION METHODOLOGY}

The evaluation of fuel sorting was developed by assembling a task team which included members from a range of sub-projects. Based on input from the team members, each major sub-project area down stream of a fuel sorting step was considered to identify requirements with the potential to be influenced by some type of fuel sorting. A criteria description was developed for each requirement which might be satisfied by a fuel element sorting scheme. Alternatives to fuel element sorting were also proposed as methods for achieving the requirement which could range from fuel canister sorting to facility design modifications.

The task team reviewed the consolidated information which resulted in the 21 potential requirements provided in Appendix $A$. The requirements were initially evaluated to identify those that could be eliminated from further consideration based on fuel sorting providing only a secondary influence on satisfying the requirement. The remaining requirements were then discussed, focusing on the proposed fuel element sorting criteria and alternatives to arrive at a group of requirements which could only be satisfied by fuel element sorting. Table 1 provides a summary of the requirements influenced by fuel or canister sorting which were determined to be resolved only by fuel element sorting. Table 1 also includes the requirements that could be satisfied by fuel element or fuel canister sorting where no alternative to some type of sorting could be proposed. Fuel canister sorting is recommended over fuel element sorting where feasible. Table 2 provides a summary of the requirements which could be achieved by fuel sorting, but had alternative methods to satisfy the requirement which did not involve sorting. The alternative considered viable is underlined in the comment column of Table 2.

\subsection{DISCUSSION}

The evaluation of fuel sorting was based on the concept that from a basin operations view point fuel element sorting activities should be minimized to minimize the complexity of activities which must be performed within the basin pool to minimize operator exposure. This competes with all requirements that could be potentially achieved by fuel element sorting and leads to a preference to only consider fuel element sorting when no other alternative is available to successfully remove the basin fuel. Canister sorting was not viewed as being as significant as fuel element sorting to increasing operator 
WHC-SD-SNF-ER-011, Rev 0

\section{Table 1. Identified Requirements Needing Fuel Element or Fuel Canister Sort to Satisfy}

\begin{tabular}{|c|c|c|}
\hline Requir rement & $\begin{array}{c}\text { Fuel Element Sorting Criterion } \\
\text { to Sat isfy Requi rement }\end{array}$ & $\begin{array}{l}\text { Comments/Alternative to Use } \\
\text { of Fuel Sorting }\end{array}$ \\
\hline \multicolumn{3}{|c|}{ REQUIREMENTS SATISFIED ONLY BY A FUEL ELEMENT SORT } \\
\hline $\begin{array}{l}\text { Fuel geometry must approach the } \\
\text { cyl indrical array geometry used in } \\
\text { the criticality analysis to be placed } \\
\text { in a fuel basket. otherwise it must } \\
\text { be placed in a basket located in the } \\
\text { end of a mco to take advantage of } \\
\text { neutron leakage. }\end{array}$ & $\begin{array}{l}\text { Sort intact, nearly intact and } \\
\text { el ement pieces that can be } \\
\text { placed in a fuel basket to form } \\
\text { stacked pieces to approach a } \\
\text { geonetry in the current } \\
\text { criticality analysis from those } \\
\text { which must be placed in an end } \\
\text { basket. }\end{array}$ & $\begin{array}{l}\text { Alternative criticality analysis } \\
\text { cases could be pursued to broaden } \\
\text { the geonetry assumptions defining } \\
\text { the element which can be placed } \\
\text { in a central fuel basket. This } \\
\text { would refine the sort criteria, } \\
\text { but not change the need to sort. }\end{array}$ \\
\hline $\begin{array}{l}\text { Satisfy recommended safeguards } \\
\text { accountability plan requiring } \\
\text { production of a MCo inventory of } \\
\text { nuclear materials using piece count } \\
\text { inventory data or weighing, depending } \\
\text { on an el ement approaching an intact } \\
\text { condition. }\end{array}$ & $\begin{array}{l}\text { Sort fuel elements/pieces based } \\
\text { on approach to an intact } \\
\text { el ement to ident ify those which } \\
\text { can be placed in the Mco } \\
\text { inventory using piece count } \\
\text { data or must be weighed for } \\
\text { inventory. }\end{array}$ & \\
\hline $\begin{array}{l}\text { Minimize number of MCO's required to } \\
\text { be procured by MCO Sub-Project by } \\
\text { maximizing use of fuel loading } \\
\text { positions. Total MCOs upper limit of } \\
440 \text { based on available CSB positions. }\end{array}$ & $\begin{array}{l}\text { Segregation of short element } \\
\text { pieces for placement in a } \\
\text { scrapholder based on a length } \\
\text { which produces efficient } \\
\text { utilization of the MCO. }\end{array}$ & $\begin{array}{l}\text { Assumes partial el ements shorter } \\
\text { than a specified length in a } \\
\text { scrapholder provides more } \\
\text { effective use of MCO space. } \\
\text { Requires a scrapholder design } \\
\text { concept to define. }\end{array}$ \\
\hline \multicolumn{3}{|c|}{ REQUIREMENTS SATISFIED BY A FUEL CANISTER SORT } \\
\hline $\begin{array}{l}\text { Limit heat generation to a specified } \\
\text { maximum or to within a known range } \\
\text { for each MCo to provide sufficient } \\
\text { margin to prevent excessive water- } \\
\text { uranium reactions at elevated fuel } \\
\text { temperatures. }\end{array}$ & $\begin{array}{l}\text { Sort fuel to achieve a heat } \\
\text { generation rate in each Mco to } \\
\text { be within a specified range. }\end{array}$ & $\begin{array}{l}\text { May be accompl ished by canister } \\
\text { sel ection planning. }\end{array}$ \\
\hline $\begin{array}{l}\text { The fuel temperature maintained at } \\
\text { less than } 400 \text { deg } F \text { during storage to } \\
\text { satisfy current CSB performance } \\
\text { specification. }\end{array}$ & $\begin{array}{l}\text { Sort fuel to achieve a heat } \\
\text { generation rate in each MCo to } \\
\text { be within a specified range. }\end{array}$ & $\begin{array}{l}\text { May be accompl ished by canister } \\
\text { selection. }\end{array}$ \\
\hline $\begin{array}{l}\text { Minimize the number of McOs } \\
\text { containing single pass reactor fuel. }\end{array}$ & $\begin{array}{l}\text { Sort to place aluminum clad } \\
\text { fuel in separate MCO(s) to } \\
\text { allow handl ing under special } \\
\text { procedures. }\end{array}$ & $\begin{array}{l}\text { Accompl ished by canister } \\
\text { selection. }\end{array}$ \\
\hline $\begin{array}{l}\text { Maintain MCO fuel configuration in } \\
\text { critically safe geometry throughout } \\
\text { processing and storage period. }\end{array}$ & $\begin{array}{l}\text { Sort fuel assemblies in } \mathrm{KW} \\
\text { Basin by length and place all } \\
\text { fuel at less than } 55 \mathrm{~cm} \text { in Mk } \\
\text { 1A baskets. }\end{array}$ & $\begin{array}{l}\text { Criticality safety required to be } \\
\text { addressed in all phases. } \\
\text { Alternative to el ement sort is to } \\
\text { assure all intact MK } 1 \mathrm{~A} \text { in } \mathrm{KW} \\
\text { Basin are placed in baskets with } \\
\text { central void core by placing all } \\
\text { fuel from octagonal top canisters } \\
\text { in Mk } 1 \mathrm{~A} \text { baskets or sort by } \\
\text { canister records. Relies on } \\
\text { proper canister loading and } \\
\text { records at time of fuel } \\
\text { discharge. }\end{array}$ \\
\hline
\end{tabular}


WHC-SD-SNF-ER-011, Rev 0

\begin{tabular}{|c|c|c|c|c|c|c|}
\hline 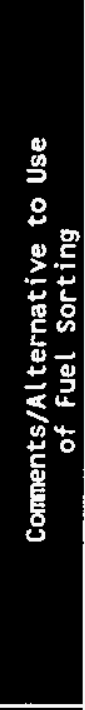 & 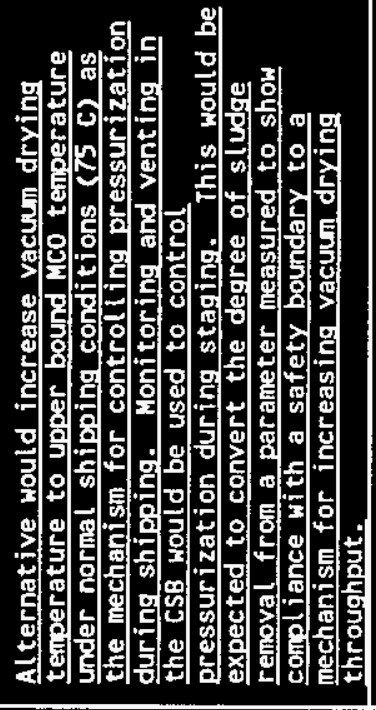 & 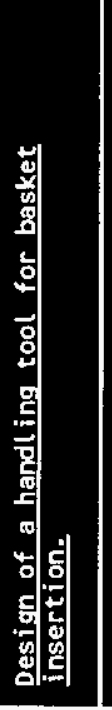 & 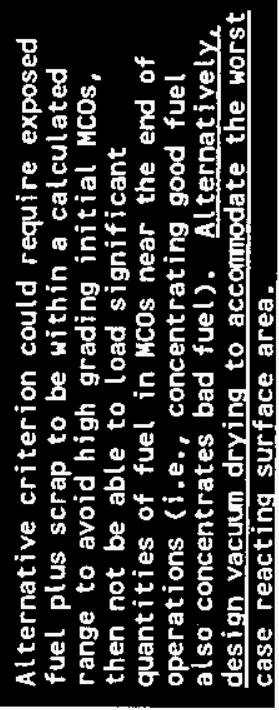 & 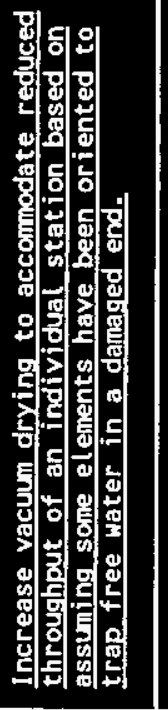 & 焉 & 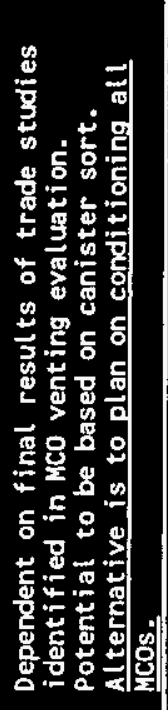 \\
\hline 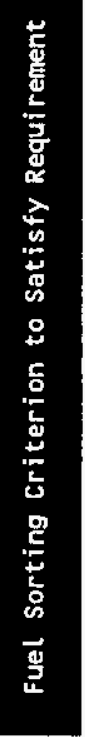 & 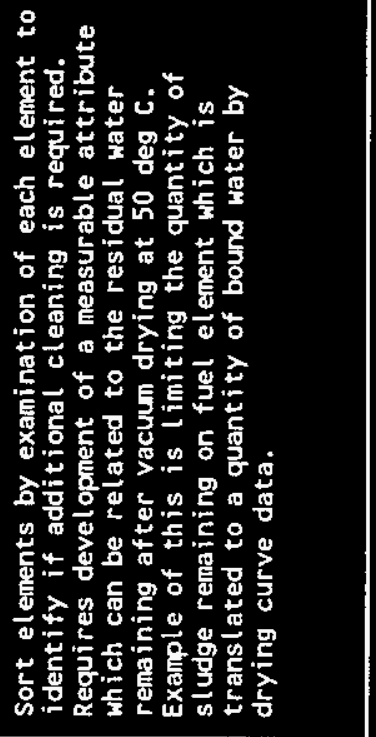 & 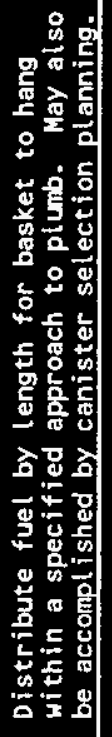 & 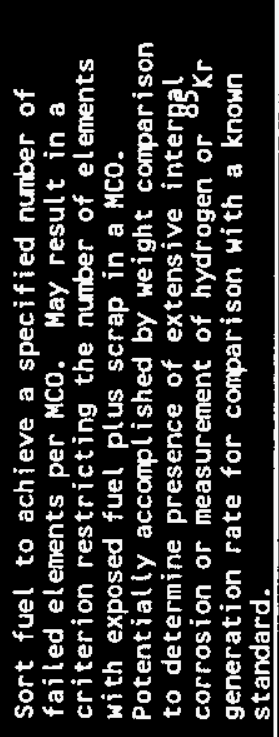 & 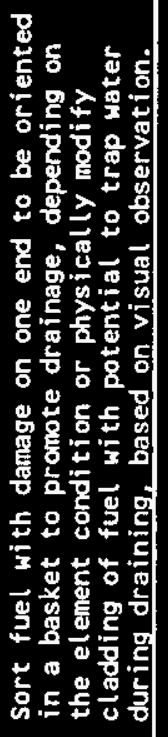 & 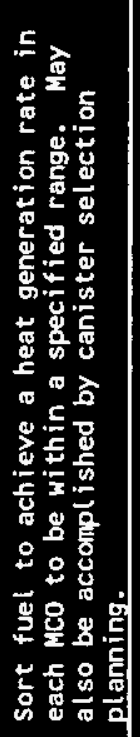 & 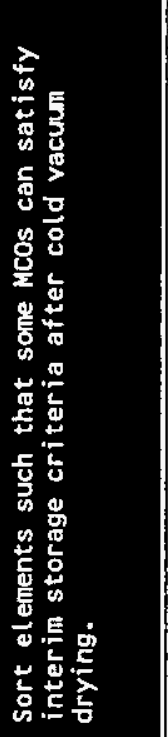 \\
\hline 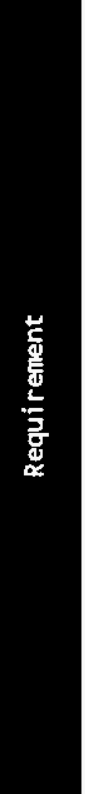 & 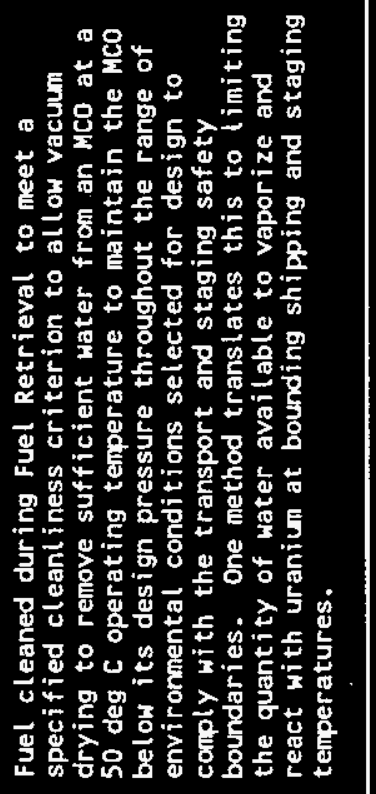 & 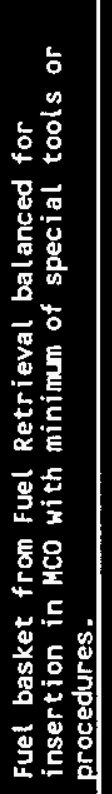 & 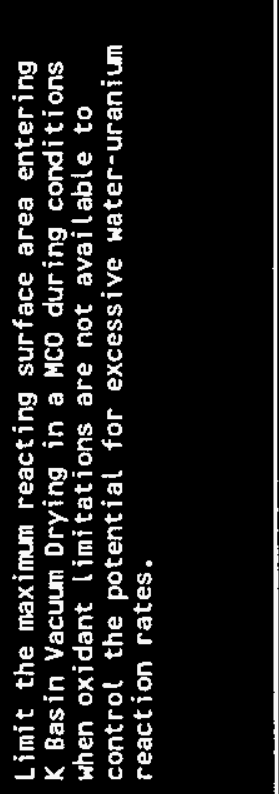 & 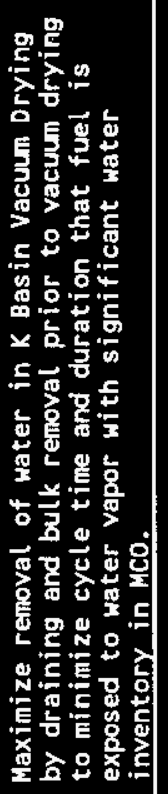 & 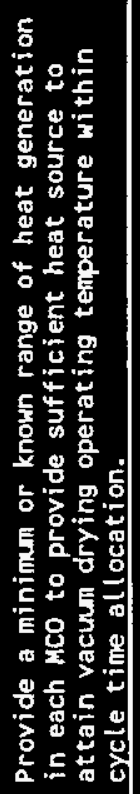 & 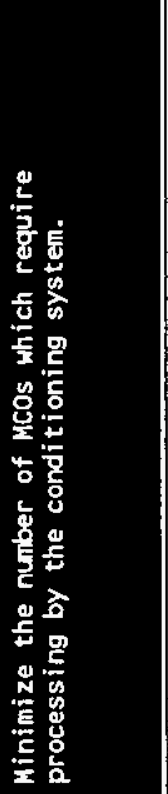 \\
\hline
\end{tabular}


WHC-SD-SNF-ER-011, Rev 0

exposure, since the piece count involved reduces from approximately 200,000 elements to approximately of 7,000 canisters.

\subsubsection{Requirements Needing Fuel Element Sorting Support}

Three requirements were identified in the sorting evaluation which could be accomplished only by fuel element sorting as indicated on Table 1 . The requirements are related to MCO utilization, support of safeguard accountability plans, and ensuring compliance with the criticality analys is developed for the MCO design. Conceptually, minimizing the number of MCOs produced will reduce near term and future costs for interim storage and future disposition of fuel. Quantification of this cost incentive has not yet been documented. However, there is an upper bound requirement driving effective utilization of each MCO embedded in the CSB performance specification limiting the total MCOs for all fuel and scrap storage to 440 MCOs. This upper bound assumes utilization of all vault storage tubes without maintaining a reserve of empty storage tubes for MCO overpacks.

Fuel sorting support for effective MCO utilization involves determining a cut off length for a partial element which should be placed in scrap holder or utilize a position in a fuel basket which would otherwise be available for longer fuel pieces. While other methods could be devised during design, one approach to this type of fuel element sorting would be to visually gage the length of each element against a go/no-go standard.

Support for safeguards accountability plans require a determination as to the extent element piece count data can be used for construction of each MCO inventory (WHC 1995f). This requires evaluating each element against a standard (not yet specified) to determine if the element can be considered intact from a safeguards perspective. Intact elements will be incorporated in the MCO inventory based on piece count data. Elements and pieces which are not sufficiently intact to use piece count data must be incorporated in the MCO inventory by a weight measurement. This identification process could be considered a form of sorting, however, the need to physically place the fuel in a specific basket based on accountability data requirements will depend on the weighing method developed during design.

The MCO criticality analysis currently relies on the fuel element geometries placed in a fuel basket loaded in center positions of the MCO approach the ideal configurations analyzed. Fuel elements which significantly depart from the ideal geometries must be located in a basket loaded on the end of the MCO in order to provide additional neutron leakage for criticality control margins. This indicates there will exist a requirement that fuel elements be evaluated to determine whether an element must be placed in a basket loaded on the end of the MCO. The criticality analys is completed to date is based on fuel elements approaching a right cylinder geometry, with the cylinder circumference intact. 
WHC-SD-SNF-ER-011, Rev 0

The system analyzed is currently under moderated such that inclusion of partial elements in a fuel basket increases the water (moderator) in the fuel array, increasing the system reactivity. Mk $1 \mathrm{~A}$ elements have been analyzed as complete assemblies, requiring that the outer element be paired with an inner element to reduce the system reactivity. Each of these attributes contribute to the sorting criteria which indicate whether a fuel element must be loaded in an end fuel basket. Specific definition of the sorting criteria could potentially be modified by a broader criticality analysis than has been completed to date.

\subsubsection{Requirements Needing Canister Sorting Support}

Four additional requirements indicated on Table 1 were identified that could be achieved by fuel canister sorting. Criticality control appears to be reasonably achieved by canister selection (applicable to $\mathrm{KW}$ Basin only). This sort is required in order to ensure that Mk $1 \mathrm{~A}$ fuel is placed in the fuel basket designed with a larger central void area to maintain criticality control during processing and storage. This approach does rely on records of canister loading and position, however there is no known reason to question these data at this time.

A separate fuel basket design has also been developed for SPR fuel which allows stacking of 10 baskets for the shorter fuel in a single MCO for efficient utilization. In addition, uncertainty exists as to the specific processing conditions which will ultimately be defined for the single pass reactor fuel. At this time, the potential exists for this fuel to require different conditions than the $N$ Reactor fuel due to the difference in cladding material. To support this potential and efficient MCO utilization, the single pass reactor fuel must be segregated in a separate $M C O(s)$. Sorting to achieve this can be accomplished by selection of canisters as current records indicate that $N$ Reactor fuel and single pass reactor fuel have not been mixed together in storage canisters.

Two additional requirements were identified related to controlling the heat generation rate of each MCO within a specified range. A decision to actually implement this criterion appears to be amenable to deferral at this point in time as designs are proceeding assuming bounding heat generation rates. Implementation of fuel canister selection could be considered at a future date and is a mechanism to provide additional conservatism that operations will always be within the design envelope of systems, or be used to resolve a currently unforeseen design problem which may arise from using the current bounding heat generation rates. 


\subsubsection{Requirements with Alternatives to Sorting}

Six requirements were identified in Table 2 which could be achieved by a fuel sorting methodology, but alternatives are available to satisfy the requirement which do not involve either fuel element or canister sorting. The first of these types of requirements involves defining an objective for the fuel cleaning step which is included in the Fuel Retrieval activities.

The initial concept of fuel cleaning was to reduce the quantity of sludge and fuel corrosion products adhering to the external surfaces of fue 1 elements to reduce the quantity of bound water transferred into an MCO. This bound water is currently assumed to remain in the MCO after vacuum drying, until the fuel has been conditioned (during transport to the CSB and while staged with in the (SB). Unfortunately, drying data for actual sludge and fuel corrosion products will not be available for some time. This requires extrapolation of the sludge drying properties from materials hypothesized to be similar, a method which inherently contains considerable uncertainty. A total water limit approach has been used as the method restricting the maximum pressure that could be generated in the MCO. This has the effect of requiring a fuel element sort based on the apparent quantity of residual sludge to identify if more aggressive cleaning is needed. The approach makes a determination of the residual sludge in each MCO process control data required to verify that fuel transport and staging is being performed within the design safety envelope.

An alternative to this approach would rely on increasing the operating temperature of the vacuum drying system to reflect the maximum design cask temperature during transport under normal conditions (75 C) (WHC 1995e). Performing vacuum drying at this temperature would then be the basis for preventing evolution of additional water vapor from contained sludge during transport and would el iminate that as a uranium reactant source. Monitoring and venting would be relied upon to control MCO pressurization during staging in the CSB where fuel temperatures could increase to $200 \mathrm{C}$. This approach decouples fuel cleaning from performing a function associated with maintaining operations within the design safety envelop. However, fuel cleaning would still be desirable to reduce the time required for vacuum drying operations to achieve equilibrium water removal. The degree of fuel cleaning then becomes a process optimization parameter which can be performed on a best effort basis without a direct verification method beyond determining that fuel cleaning vigilance must be improved if vacuum drying cycles start to become unreasonable to meet production requirements.

Fuel element sorting could be used to distribute fuel by length around an MCO basket such that the free hanging basket is sufficientiy close to plumb that it can be inserted in an MCO without the aid of special tools. The alternative to this approach would be to provide tools to aid in the MCO basket insertion that widens the tolerance band around hanging plumb such that sorting for this parameter is not required. 
WHC-SD-SNF-ER-011, Rev 0

Fuel element sorting could be used to attempt to 1 imit the reacting fuel surface area in an MCO prior to introduction into vacuum drying. This would be achieved by measuring the hydrogen or ${ }^{85} \mathrm{Kr}$ generation rate from a fuel element for comparison with a standard that has been developed from experimental data. A more practical variation of this sorting would be to perform the measurement on a basket of fuel or MCO filled with fuel. Excessive reaction rates would indicate that some, or all of the fuel elements contained in the measure fuel group would need to be recycled through the fuel cleaning station or addressed by special cleaning methods to reduce the reacting surface area. An alternative to this approach is to ensure the vacuum drying system design envelop is broad enough to accommodate the worst case reacting surface area, or develop a special drying procedure similar to that required for scrap.

Fuel element sorting could be used to identify fuel with damaged ends that could trap bulk water with in the residual cladding. In its simplest form, the damaged ends could be oriented down in the fuel basket to promote drainage of bulk water. More complex damage patterns could require physical modification of the residual cladding to promote water drainage which would entail routing the identified fuel elements through a special fuel preparation line. An alternative to this type of sorting is to increase the vacuum drying time based on assuming some elements contain water which does not drain. This may result in an increase in the number of drying stations.

Fuel element or canister sorting to achieve a known heat generation rate range for each MCO could be used as an alternative to provide a minimum heat generation rate in support of vacuum drying heatup. This can also be accomplished by sizing the vacuum drying heating system to accommodate the required cycle time assuming no heat generated by the MCO.

Fuel element or canister sorting based on the surface condition of fuel elements has been proposed as a method to reduce the quantity of fuel requiring conditioning prior to insertion into interim storage. This concept is under evaluation as part of a study of alternatives to MCO venting during staging in the CSB. At this time, designs are proposed to proceed assuming all MCOs will be conditioned prior to placing in interim storage (WHC 1995g).

\subsection{RECOMMENDATION}

Schedule requirements for the Spent Nuclear Fuel Project require that a recommendation on fuel sorting be provided based on incomplete data. The recommendations which follow, if accepted, allows the project to proceed at risk. The evaluation identifies concerns that could be satisfied by fuel sorting, but had alternatives that could be proposed. Since operator exposure is likely minimized by minimizing activities in the basin, it is recommended that designs proceed assuming the requirements in Table 2 above are pursued by the alternatives similar to those presented in the evaluation. This includes 


$$
\text { WHC-SD-SNF-ER-011, Rev } 0
$$

a best effort washing or mechanical cleaning of each fuel element to minimize fuel corrosion products and sludge added to the MCO. However, a quantitative measure of the residual sludge would not be required, assuming proposed modifications to vacuum drying and staging systems are implemented. It should be noted that acceptance of the a recommendation which limits the requirements satisfied by fuel sorting must at the same time accept that these other concerns will be pursued by an alternative method. If further design efforts indicate the proposed alternatives are impractical, additional sorting criteria would need to be developed for inclusion in the design. The following represents the recommended fuel sorting functions and requirements for the SNFP based on the data available at this time.

\subsection{SPECIFIC FUEL SORTING RECOMHENDATIONS}

1. A fuel sorting function should be included in the Fuel Retrieval system design criteria.

Basis: The recommended path for design activities at this time is to assume a combination of fuel element sorting, fuel canister sorting, and alternatives to sorting to address the requirements identified in this study as potentially resolved by sorting. The evaluation described in Section 3.0 identified a number of requirements which could only be satisfied by sorting both fuel elements and fuel canisters. It is unlikely that new concepts can be developed for satisfying all of these requirements to eliminate the need for some fuel sorting.

2. A requirement to perform fuel canister sorting is recommended to ensure the MK IA fuel in KW Basin is loaded in the proper design MCO basket.

Basis: This requirement originates from the criticality analys is for the MCO design. A MCO design concept has been selected which uses a central void core to maintain criticality control of the higher uranium enrichment of Mk $1 \mathrm{~A}$ fuel when placed in the fuel basket array (WHC 1995d). The central void core is not required for criticality control of Mk IV fuel and separate basket designs have been developed for each fuel type in order to maximize fuel element loading in an MCO. The separate basket designs require that Mk $1 \mathrm{~A}$ fuel be loaded in the proper design of basket. However, this requirement does not preclude the option of placing shorter Mk IV elements in baskets with Mk $1 \mathrm{~A}$ elements.

3. A requirement to perform fuel canister sorting is recommended to segregate MCOs containing SPR fuel from MCOS containing N Reactor fuel.

Basis: This requirement provides for efficient utilization of the MCO by placing the SPR in shorter baskets, commensurate with the shorter SPR fuel length. The segregation also supports a projection that unique processing conditions will need to be developed to dry and condition the aluminum clad 
WHC-SD-SNF-ER-011, Rev 0

SPR fuel (undocumented). Development of these conditions has not been initiated due to the small quantity of SPR fuel which must be processed. It is unlikely that development of the SPR fuel processing conditions will be initiated until after much of the sub-project design activities are complete.

4. A requirement to perform fuel element sorting is recommended for differentiating between elements incorporated into the MCO inventory by piece count data or weighing.

Basis: The nuclear material accountability plan recommends construction of the nuclear material inventory loaded in each MCO from existing bas in accountability data (WHC 1995f). This is proposed to be accomplished for essentially intact elements by transfer of existing data for each canister to the specific MCO for construction of inventory data. The recommended nuclear material accountability plan relies on application of existing piece count data to the maximum extent possible for intact or nearly intact elements, but requires determining a weight of all pieces added to the MCO that can not be considered a full element. Development of a criterion defining the approach to a complete element which allows use of the piece count data is not currently available to provide a specific sorting criterion.

5. A requirement to perform fuel element sorting to determine if an element or assembly is long enough to be loaded in a fuel basket position or placed in a scrapholder, should not be incorporated in current design activities at this time.

Basis: The CSB Performance Specification limits the total number of MCOs to 440. The potential exists for this maximum total to be reduced if it is determined that CSB vault tube positions must be reserved for MCO overpacks. Current estimates of the MCOs generated during removal of fuel from $\mathrm{K}$ Basins is 398, allocating 54 baskets for scrapholders. In addition, minimizing the number of MCOs produced is projected to minimize near term and future disposition costs (undocumented). The limited CSB capacity available for increasing the total of MCOS could result in this factor becoming a sorting requirement in the future. However, a firmer concept description of the scrapholder design is required to specify the length used as a sorting criterion to determine when fuel pieces are placed in a scrapholder for efficient MCO utilization. The second study in Section 4.2 must be completed to establish if this type of sorting is required.

6. A requirement to perform fuel element sorting to identify whether fuel can be loaded in a fuel basket which can be located at any position within the MCO or must be included in a basket positioned in the end of a MCO to satisfy the MCO criticality analys is should not be incorporated incurrent design activities at this time.

Basis: While the MCO criticality analyses is not completely documented, the available analysis indicates that a decision point potentially exists for determining if an element approaches the analyzed geometries to allow loading in a fuel basket which is located in a central position of the MCO. Fuel 
elements which significantly depart from the analyzed geometries must be placed in a fuel basket positioned on the end of a MCO to take advantage of additional neutron leakage to maintain the required criticality control margins. The current analys is is based on the central MCO fuel baskets containing cylindrical shaped fuel assemblies and assumes Mk $1 \mathrm{~A}$ assemblies must contain an inner element. This definition is not considered specific enough for actual implementation and a parametric study of the criticality analysis will be required to define a practical sorting criterion on fuel geometry. The third and fourth studies in Section 4.2 must be completed to establish if this type of sorting is required.

7. A requirement for fuel canister sorting or other actions directed toward narrowing the MCO heat generation variability should not be incorporated in current design activities.

Basis: It is recommended that designs proceed assuming no canister sorting in support of adjusting the heat generation rate of MCOs at this time, but to continue activities evaluating the ability to narrow this parameter during operations. Sub-project designs are currently proceeding based on the maximum predicted heat load in a MCO that could be experienced by filling a MCO with fuel elements containing the highest specific heat generation rate predicted to exist in the basins. Therefore, system designs will be able to accommodate SNFP activities without sorting to narrow the heat generation variability. However, canister sorting could provide additional margin during operation to ensure that MCOS generated are conservatively within the system design envelopes or provide a contingency that could be used to resolve currentiy unforseen design problems that may develop during detailed design.

\subsection{RECOMMENDED ADDITIONAL STUDIES}

The following additional studies have been identified in the course of the evaluation which are required to allow specification of fuel sorting criteria in sufficient detail such that they can actually be implemented in the design process. These trade studies have not been included in the trade studies 1ist presented in WHC, 1995C.

- Development of a clear definition of an intact element for the purposes of applying accountability piece count data in constructing the MCO inventory (Supports Recommendation 4, recommend assigning responsibility to the Fuel Retrieval Sub-Project as the definition may be dependent on the overall approach selected for implementing the recommended accountability plan). 


$$
\text { WHC-SD-SNF-ER-011, Rev } 0
$$

- Develop the scrapholder design concept followed by a MCO volume utilization trade-off study to set a fuel length sorting criteria for placing a fuel piece in a fuel basket or scrapholder (Supports Recommendation 5, recommend assigning responsibility to the MCO SubProject).

- Complete documentation of current MCO criticality analysis (Supports Recommendation 6 , recommend assigning responsibility to the MCO SubProject).

- Develop a practical definition of fuel loading geometries which meet the MCO criticality analysis bounding conditions. This could be accomplished by evaluating the impact of implementing the current MCO criticality analysis on fuel basket loading, or reevaluating the criticality analysis with non-ideal fuel geometry assumptions to identify if criticality control margins can be attained with less restrictive assumptions. (Supports Recommendation 6, recommend assigning responsibility to the MCO Sub-Project.) 


\section{WHC-SD-SNF-ER-011, Rev 0}

\subsection{REFERENCES}

WHC, 1995a WHC-SD-SNF-TI-015, (Rev 0), Compiled by SM Short and MM Beary, "Spent Nuclear Fue1 Project Technical Databook", Prepared by Pacific Northwest Laboratory for Westinghouse Hanford Company, Richland, Washington.

WHC, 1995b WHC-SD-SNF-SP-005, (Rev 0), "Hanford Spent Nuclear Fuel Project Integrated Process Strategy for K Basins Spent Fuel, "Volumes 1\&2, Westinghouse Hanford Company, Richland, Washington.

WHC, 1995c WHC-SD-SNF-SD-005, (Rev 0), "Spent Nuclear Fuel Project Technical Baseline Description Fiscal Year 1996," Volumes 182, Westinghouse Hanford Company, Richland, Washington.

WHC, 1995d WHC-S-0246, (Rev OA), DRAFT, "Performance Specification for the Spent Nuclear Fuel Multi-Canister Overpack, "Westinghouse Hanford Company, Richland, Washington.

WHC, 1995e WHC-S-0396, (Rev 1), "Specification for SNF Path Forward Cask and Transportation System, "Westinghouse Hanford Company, Richland, Washington.

WHC, 1995f WHC-SD-SNF-SP-007, (Rev 0), "Recommendation for Safeguards Accountability for Fuel Removal from K Basins, "Westinghouse Hanford Company, Richland, Washington.

WHC, 1995g WHC-SD-SNF-ES-017, (Rev 0), "Hanford Spent Nuclear Fuel Project Evaluation of Multi-Canister Overpack Venting and Monitoring Options During Staging of K Basins Fuel, "Westinghouse Hanford Company, Richland, Washington. 
WHC-SD-SNF-ER-011, Rev 0

\subsection{ACKNOYLEDGEMENT}

The following personnel participated in the task team assembled to evaluate the fuel sorting issue.

RG Cowan

JR Frederickson

LH Goldmann

JJ Irwin

$K$ Iyengar

CR Miska

GS Voyles

JC Wiborg 
WHC-SD-SNF-ER-011, Rev 0

Appendix A

Summary of Potential Requirements Considered

for Influence by Fuel Sorting

A- $\mathbf{i}$ 


\begin{tabular}{|c|c|c|c|c|}
\hline Activity & Requi rement & $\begin{array}{l}\text { Fuel Element Sorting } \\
\text { Criterion to Sat isfy } \\
\text { Requi rement }\end{array}$ & $\begin{array}{c}\text { Comments/Alternative to Use } \\
\text { of Fuel Sorting }\end{array}$ & $\begin{array}{l}\text { Requirement } \\
\text { Assessment }\end{array}$ \\
\hline \multirow[t]{4}{*}{$\begin{array}{l}\text { 1. Fuel } \\
\text { Retrieval }\end{array}$} & $\begin{array}{l}\text { a) Minimize actions which increase } \\
\text { equipment installation, number of } \\
\text { operators, or time to produce a fuel } \\
\text { basket in the basin, minimizing operator } \\
\text { exposure. }\end{array}$ & $\begin{array}{l}\text { Impose as few sorting } \\
\text { criteria as possible. }\end{array}$ & & \\
\hline & $\begin{array}{l}\text { b) Fuel cleaned during Fuel Retrieval to } \\
\text { meet a specified cleanl iness criterion } \\
\text { to allow vacuun drying to remove } \\
\text { sufficient water from an Mco at a } 50 \text { deg } \\
\text { C operating temperature to maintain the } \\
\text { MCo below its design pressure throughout } \\
\text { the range of environmental conditions } \\
\text { selected for design to comply with the } \\
\text { transport and staging safety boundaries. } \\
\text { One method translates this to limiting } \\
\text { the quantity of water available to } \\
\text { vaporize and react with uranium at } \\
\text { bounding shipping and staging } \\
\text { temperatures. }\end{array}$ & $\begin{array}{l}\text { Sort elements by examination } \\
\text { of each element to identify } \\
\text { if additional cleaning is } \\
\text { required. Requires } \\
\text { development of a measurable } \\
\text { attribute which can be } \\
\text { related to the residual water } \\
\text { renaining after vacuun drying } \\
\text { at } 50 \text { deg c. Example of this } \\
\text { is limiting the quantity of } \\
\text { sludge renaining on fuel } \\
\text { element which is translated } \\
\text { to a quantity of bound water } \\
\text { by drying curve data. }\end{array}$ & $\begin{array}{l}\text { Alternative would increase } \\
\text { vacum drying temperature to } \\
\text { upper bound Mco temperature } \\
\text { under normal shipping conditions } \\
\text { ( } 75 \text { C) as the mechanism for } \\
\text { controll ing pressurization } \\
\text { during shipping. Monitoring and } \\
\text { venting in the css would be used } \\
\text { to control pressurization during } \\
\text { staging. This would be expected } \\
\text { to convert the degree of sludge } \\
\text { removal from a paraneter } \\
\text { measured to show compl iance with } \\
\text { a safety boundary to a mechanism } \\
\text { for increas ing vacuum drying } \\
\text { throughout. }\end{array}$ & A \\
\hline & $\begin{array}{l}\text { c) Maximize fuel cleaning throughput } \\
\text { with a minimum of equipment installed in } \\
\text { the basin. }\end{array}$ & $\begin{array}{l}\text { Sort fuel visually to handle } \\
\text { intact el enents in one line, } \\
\text { shunt ing unsound elements to } \\
\text { another line allocated to use } \\
\text { more cleaning time per } \\
\text { element. }\end{array}$ & $\begin{array}{l}\text { If multiple lines required, use } \\
\text { both lines to handle elements as } \\
\text { they come and utilize queuing to } \\
\text { accomodate periods of higher } \\
\text { and lower fuel cleaning } \\
\text { throughput. }\end{array}$ & \\
\hline & $\begin{array}{l}\text { d) Fuel basket balanced for insertion in } \\
\text { MCO with minimull of special tools or } \\
\text { procedures. }\end{array}$ & $\begin{array}{l}\text { Distribute fuel by length for } \\
\text { basket to hang within a } \\
\text { specified approach to plumb. }\end{array}$ & $\begin{array}{l}\text { May be accomplished by canister } \\
\text { selection planning or design of } \\
\text { a handl ing toot for basket } \\
\text { insertion. }\end{array}$ & A \\
\hline 2. MCO & $\begin{array}{l}\text { a) Minimize number of MCO's required by } \\
\text { maximizing use of fuel loading } \\
\text { positions. Total MCO upper limit of } 440 \\
\text { based on available CSB positions. }\end{array}$ & $\begin{array}{l}\text { Visual segregation of intact } \\
\text { elements from partial } \\
\text { elements. NEED TO DEVELOP A } \\
\text { DEFINITION OF SCRAP. }\end{array}$ & $\begin{array}{l}\text { Assumes partial el ements in } \\
\text { scrap holder provides more } \\
\text { effective use of Mco space. }\end{array}$ & $\mathbf{s}$ \\
\hline
\end{tabular}

Assessment Codes:

A - Requirement can be achieved by an alternative to fuel element sorting. The alternative is adequate to achieve requirentent and is qualitatively expected to be less expensive or result in reduced operator exposure.

s - Requirement can only be achieved by fuel element sorting.

$x$ - Requirement is not readily influenced by fuel element sorting. 
WHC-SD-SNF-ER-011, Rev 0

\begin{tabular}{|c|c|c|c|c|c|}
\hline 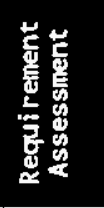 & $x$ & $<$ & $<$ & $<$ & $<$ \\
\hline 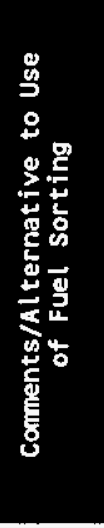 & 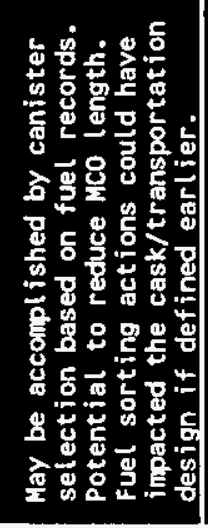 & 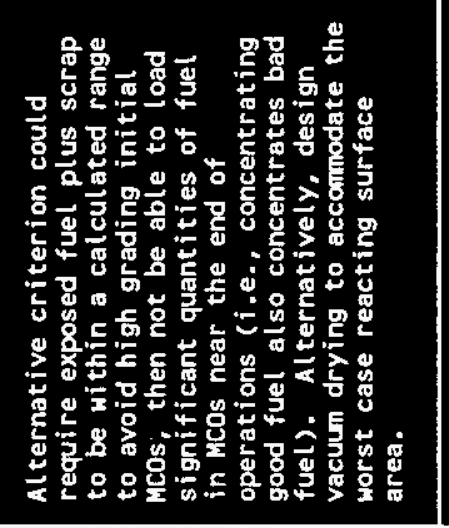 & 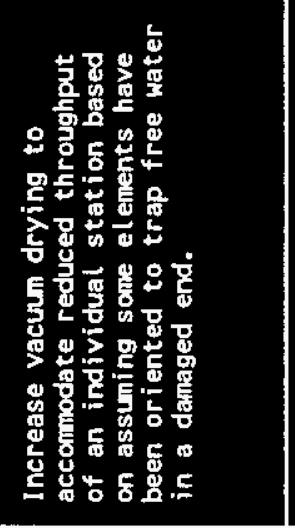 & 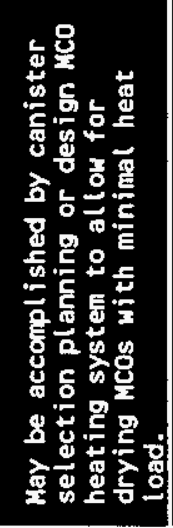 & 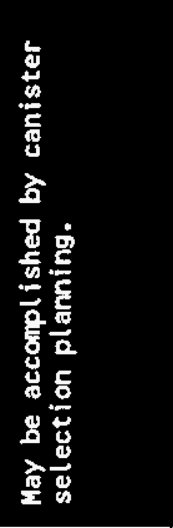 \\
\hline 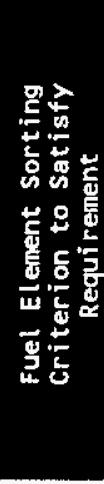 & 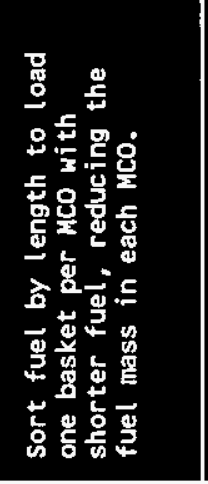 & 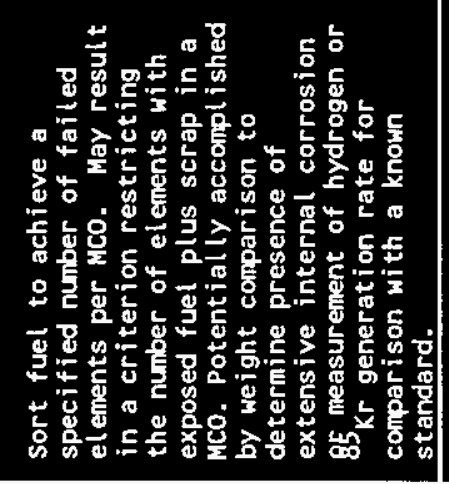 & 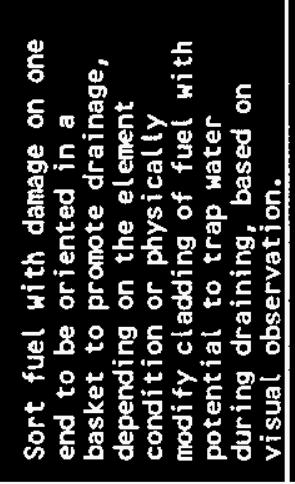 & 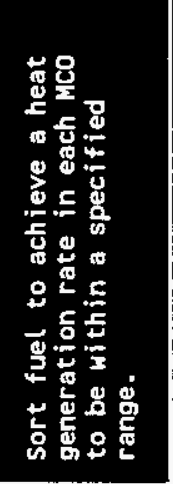 & 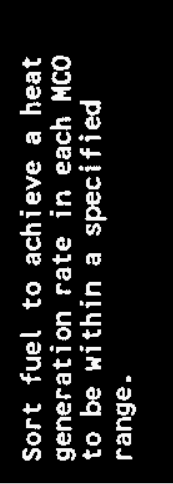 \\
\hline & 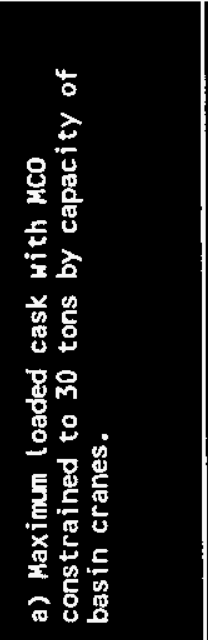 & 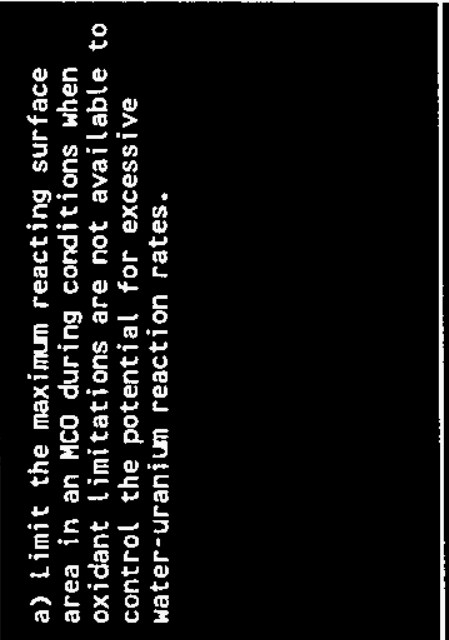 & 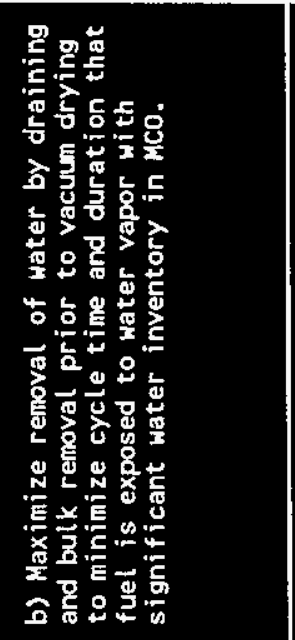 & 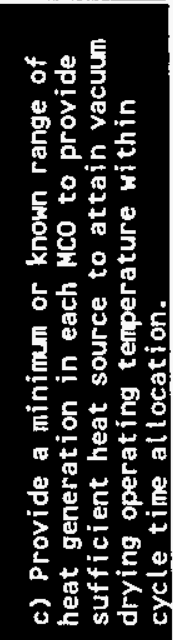 & 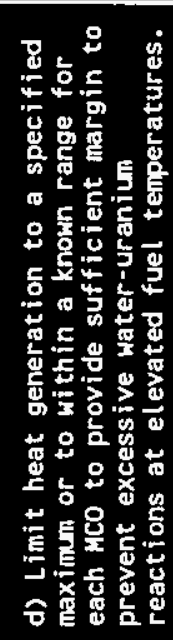 \\
\hline 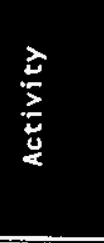 & 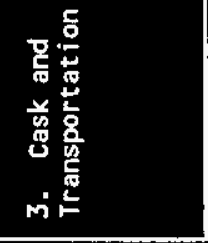 & 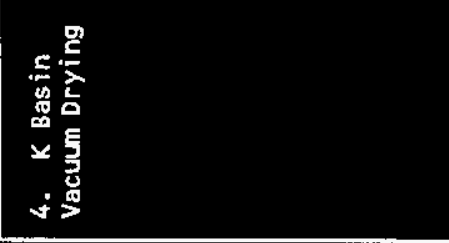 & & & \\
\hline
\end{tabular}


Table A.1 Assessment of Potential Requirements Considered Influenced by Fuel Sorting (Sheet 2 of 5)

\begin{tabular}{|c|c|c|c|c|}
\hline Activity & Requirement & $\begin{array}{l}\text { Fuel El ement sorting } \\
\text { Criterion to Sat isfy } \\
\text { Requirement }\end{array}$ & $\begin{array}{c}\text { Comments/Alternative to Use } \\
\text { of Fuel Sorting }\end{array}$ & $\begin{array}{l}\text { Requir entent } \\
\text { Assessment }\end{array}$ \\
\hline \multirow[t]{5}{*}{$\begin{array}{l}\text { 5. Canister } \\
\text { Storage } \\
\text { Building }\end{array}$} & $\begin{array}{l}\text { a) Maximum individuat MCO heat load less } \\
\text { than } 852 \mathrm{H} \text { per MCO to satisfy current } \\
\text { CSB performance specification. }\end{array}$ & $\begin{array}{l}\text { No sorting required to } \\
\text { satisfy if fuel transfers } \\
\text { started after } 12 / 31 / 97 \text {. }\end{array}$ & $\begin{array}{l}\text { If fuel transfer started prior } \\
\text { to } 12 / 31 / 97 \text {, older fuel keys can } \\
\text { be selected based on records } \\
\text { unt il after } 12 / 31 / 97 \text {. }\end{array}$ & $x$ \\
\hline & $\begin{array}{l}\text { b) Control the heat load of MCOs to } \\
\text { produce a loading pattern which allows } \\
\text { all fuel to be interim stored at } \\
\text { approximately the same temperature. }\end{array}$ & $\begin{array}{l}\text { Sort fuel to achieve a } \\
\text { specified pattern of heat } \\
\text { generation rates in the MCOs. }\end{array}$ & $\begin{array}{l}\text { This is not the sane as making } \\
\text { the individual mco heat load } \\
\text { approximately constant. May be } \\
\text { accompl ished by canister } \\
\text { selection. May also be } \\
\text { accompl ished by Mco sorting } \\
\text { after a confirmatory measurement } \\
\text { during vacuum drying. }\end{array}$ & $x$ \\
\hline & $\begin{array}{l}\text { c) Allow placement of any MCO in any } \\
\text { tube position within the CSB to simplify } \\
\text { facility operations. }\end{array}$ & $\begin{array}{l}\text { Sort fuel to approach a } \\
\text { constant heat load in each } \\
\text { MCO. }\end{array}$ & $\begin{array}{l}\text { May be accomplished by canister } \\
\text { selection to load an ico from a } \\
\text { mixture of keys. }\end{array}$ & $x$ \\
\hline & $\begin{array}{l}\text { d) The fuel temperature maintained at } \\
\text { less than } 400 \text { deg } F \text { during storage to } \\
\text { sat isfy current CSB performance } \\
\text { specification. }\end{array}$ & & $\begin{array}{l}\text { May be accompl ished by canister } \\
\text { selection. }\end{array}$ & A \\
\hline & $\begin{array}{l}\text { e) Produce MCOs of known heat load to } \\
\text { support csB startup (heatup). }\end{array}$ & & $\begin{array}{l}\text { Accompl ished by canister } \\
\text { selection and possibly from data } \\
\text { obtained during vacuum drying. }\end{array}$ & $x$ \\
\hline \multirow[t]{2}{*}{$\begin{array}{l}6 . \\
\text { Conditioning }\end{array}$} & $\begin{array}{l}\text { a) Minimize the number of MCOs which } \\
\text { require processing by the conditioning } \\
\text { system. }\end{array}$ & $\begin{array}{l}\text { Sort elements according to } \\
\text { cladding integrity } \\
\text { attribute(s) (i.e., may } \\
\text { indicate presence of hydrates } \\
\text { and hydrides) such that some } \\
\text { Mcos can satisfy interim } \\
\text { storage criteria after cold } \\
\text { vacuum drying. }\end{array}$ & $\begin{array}{l}\text { Dependent on final results of } \\
\text { trade studies identified in MCO } \\
\text { venting evaluation. Potent ial to } \\
\text { be based on canister sort. } \\
\text { Alternative is to plan on } \\
\text { conditioning all mcos. }\end{array}$ & A \\
\hline & $\begin{array}{l}\text { b) Minimize the number of MCOs } \\
\text { containing single pass reactor fuel. }\end{array}$ & $\begin{array}{l}\text { Sort to place aluninum clad } \\
\text { fuel in separate } \operatorname{McO}(s) \text { to } \\
\text { all low handling under special } \\
\text { procedures. }\end{array}$ & $\begin{array}{l}\text { Accompl ished by canister } \\
\text { selection. }\end{array}$ & A \\
\hline
\end{tabular}

Assessment Codes:

A - Requirenent can be achieved by an alternative to fuel elenent sorting. The al ternative is adequate to achieve requirenent and is qualitatively expected to be less expensive or result in reduced operator exposure.

s - Requirement can only be achieved by fuel element sorting.

$x$ - Requirement is not readily influenced by fuel element sorting. 
WHC-SD-SNF-ER-011, Rev 0

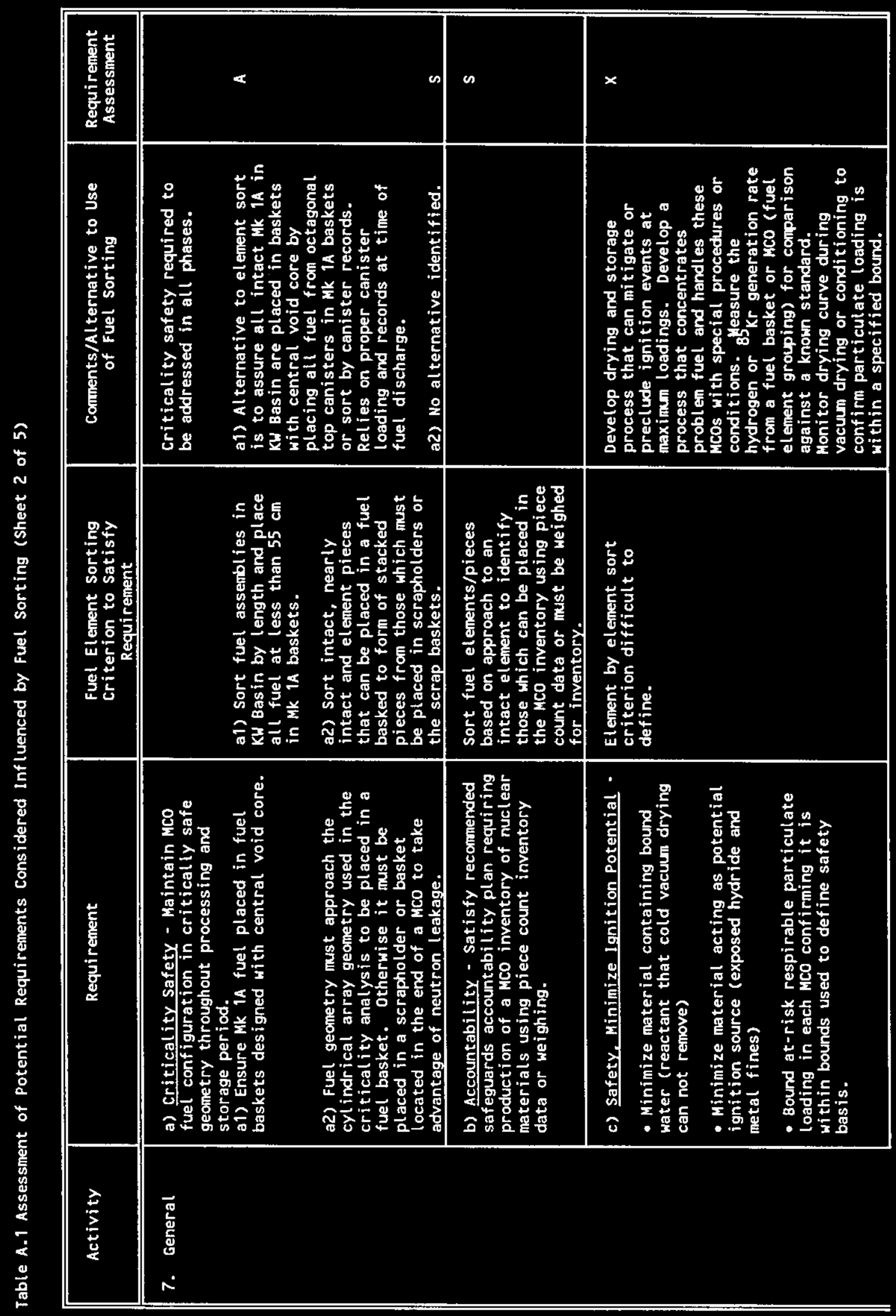

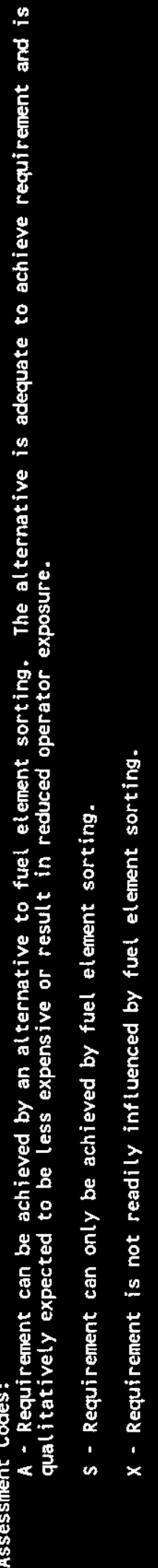


Table A.1 Assessment of Potential Requirements Considered Influenced by Fuel Sorting (Sheet 2 of 5)

\begin{tabular}{|c|c|c|c|c|}
\hline Activity & Requi rement & $\begin{array}{c}\text { Fuel Element Sorting } \\
\text { Criterion to Sat isfy } \\
\text { Requirement }\end{array}$ & $\begin{array}{c}\text { Comments/Alternative to Use } \\
\text { of Fuel Sorting }\end{array}$ & $\begin{array}{l}\text { Requi r ement } \\
\text { Assessment }\end{array}$ \\
\hline & $\begin{array}{l}\text { d) Safety, Minimize Accident Source Term } \\
\text { - Reduce the accident source term for an } \\
\text { MCo which must be accommodated in safety } \\
\text { analys is evaluations defining accident } \\
\text { mitigation systems. }\end{array}$ & $\begin{array}{l}\text { Sort fuel el ements to } \\
\text { level ize the quantity of key } \\
\text { radionucl ides in each MCO, } \\
\text { reducing the peak source term } \\
\text { which must be used in } \\
\text { accident analyses. Primarily } \\
\text { would level load the Pu-Am } \\
\text { content which is approximated } \\
\text { by level ized heat load. }\end{array}$ & $\begin{array}{l}\text { Unl ikely to significantly impact } \\
\text { the accident source term by this } \\
\text { method as failure to adequately } \\
\text { sort could be considered an } \\
\text { accident. Any actions to } \\
\text { levelize the Mco heat load would } \\
\text { likely have the effect of } \\
\text { levelizing the source term. }\end{array}$ & $x$ \\
\hline
\end{tabular}

Assessment Codes:

A - Requirement can be achieved by an alternative to fuel element sorting. The alternative is adequate to achieve requirement and is qual itatively expected to be less expensive or result in reduced operator exposure.

s - Requirenent can only be achieved by fuel element sorting.

$X$ - Requirement is not readily influenced by fuel element sorting. 


\section{DISTRIBUTION SHEET}

\begin{tabular}{|c|c|c|c|c|c|}
\hline \multirow{2}{*}{$\begin{array}{l}\text { To } \\
\text { Spent Nuclear Fuel Project }\end{array}$} & \multirow{2}{*}{\multicolumn{3}{|c|}{$\begin{array}{l}\text { From } \\
\text { Technical Issue Management } \\
\text { Board }\end{array}$}} & \multicolumn{2}{|c|}{ Page 1 of 2} \\
\hline & & & & \multicolumn{2}{|c|}{ Date $01 / 25 / 96$} \\
\hline \multirow{2}{*}{$\begin{array}{l}\text { Project Title/Work Order } \\
\text { Fuel Sorting Issue Resolution }\end{array}$} & & & & \multicolumn{2}{|c|}{ EDT No. 612993} \\
\hline & & & & \multicolumn{2}{|c|}{ ECN No. ${ }^{\circ}$ N/A } \\
\hline Name & MSIN & $\begin{array}{l}\text { Text } \\
\text { With All } \\
\text { Attach. }\end{array}$ & Text Only & $\begin{array}{l}\text { Attach./ } \\
\text { Appendix } \\
\text { Only }\end{array}$ & $\begin{array}{c}\text { EDT/ECN } \\
\text { Only }\end{array}$ \\
\hline $\begin{array}{l}\text { C. J. Alderman } \\
\text { F. W. Bradshaw } \\
\text { D. C. Bryson } \\
\text { B. S. Carlisle } \\
\text { R. F. Creed } \\
\text { J. B. Crystal } \\
\text { R. G. Cowan } \\
\text { G. E. Culley (4) } \\
\text { K. D. Daschke } \\
\text { C. Defigh-Price } \\
\text { J. C. Devine } \\
\text { J. R. Frederickson } \\
\text { J. C. Fulton } \\
\text { W. D. Gallo } \\
\text { L. J. Garvin III } \\
\text { E. W. Gerber } \\
\text { L. H. Goldmann } \\
\text { C. A. Hansen } \\
\text { R. M. Hiegel } \\
\text { J. J. Irwin } \\
\text { A. T. Kee } \\
\text { C. B. Loftis } \\
\text { P. G. Loscoe } \\
\text { M. K. Mahaffey } \\
\text { R. L. McCormack } \\
\text { G. R. Mezger } \\
\text { C. R. Miska } \\
\text { G. C. Mooers III } \\
\text { F. W. Moore } \\
\text { R. P. Omberg } \\
\text { A. L. Pajunen } \\
\text { D. R. Precechtel } \\
\text { M. A. Reilly } \\
\text { K. M. Schierman } \\
\text { J. P. Schmidt } \\
\text { P. A. Scott } \\
\text { E. D. Sellers } \\
\text { E. J. Shen } \\
\text { P. K. Shen } \\
\text { D. L. Sherreil } \\
\text { D. W. Siddoway } \\
\text { D. H. Smith } \\
\text { K. E. Smith } \\
\text { J. A. Swenson } \\
\text { D. S. }\end{array}$ & $\begin{array}{l}\text { R3-48 } \\
\text { R3-85 } \\
\text { S7-41 } \\
\text { R3-85 } \\
\text { X3-85 } \\
\text { X3-85 } \\
\text { R3-86 } \\
\text { R3-86 } \\
\text { R3-85 } \\
\text { X3-79 } \\
\text { R3-82 } \\
\text { R3-86 } \\
\text { R3-11 } \\
\text { R3-85 } \\
\text { R3-85 } \\
\text { R3-86 } \\
\text { R3-86 } \\
\text { S7-41 } \\
\text { S7-41 } \\
\text { R3-86 } \\
\text { R3-86 } \\
\text { S7-41 } \\
\text { S7-41 } \\
\text { R3-85 } \\
\text { R3-86 } \\
\text { S7-41 } \\
\text { R3-86 } \\
\text { R3-11 } \\
\text { X3-85 } \\
\text { R3-85 } \\
\text { R3-86 } \\
\text { R3-48 } \\
\text { R3-86 } \\
\text { S7-41 } \\
\text { X3-98 } \\
\text { R3-87 } \\
\text { S7-41 } \\
\text { R3-86 } \\
\text { R3-87 } \\
\text { R3-86 } \\
\text { X3-71 } \\
\text { X3-80 } \\
\text { R3-85 } \\
\text { R3-11 }\end{array}$ & $\begin{array}{l}X \\
E D T \\
E D T \\
X \\
E D T \\
E D T \\
X \\
X \\
E D T \\
E D T \\
X \\
E D T \\
X \\
E D T \\
E D T \\
X \\
E D T \\
X \\
X \\
E D T \\
X \\
X \\
X \\
E D T \\
X \\
X \\
X \\
E D T \\
E D T \\
X \\
E D T \\
X \\
E D T \\
X \\
X \\
E D T \\
E D T \\
E D T \\
E D T \\
E D T \\
E D T \\
E D T \\
X\end{array}$ & $\begin{array}{l}\text { and Item } 1 \\
\text { and Item } 1 \\
\text { and Item } 1 \\
\text { and Item } 1 \\
\text { and Item } 1 \\
\text { and Item } 1 \\
\text { and Item I } \\
\text { and Item } 1 \\
\text { and Item } 1 \\
\text { and Item } 1 \\
\text { and Item } 1 \\
\text { and Item } 1 \\
\text { and Item } 1 \\
\text { and Item } 1 \\
\text { and Item } 1 \\
\text { and Item } 1 \\
\text { and Item } 1 \\
\text { and }\end{array}$ & $\begin{array}{l}\text { only } \\
\text { only } \\
\text { only } \\
\text { only } \\
\text { only } \\
\text { only } \\
\text { only } \\
\text { only } \\
\text { only } \\
\text { only }\end{array}$ & \\
\hline
\end{tabular}




\begin{tabular}{|c|c|c|c|c|c|}
\hline \multicolumn{6}{|c|}{ DISTRIBUTION SHEET } \\
\hline To & \multirow{2}{*}{\multicolumn{3}{|c|}{$\begin{array}{l}\text { From } \\
\text { Technical Issue Management } \\
\text { Board }\end{array}$}} & \multicolumn{2}{|l|}{ Page 2 of 2} \\
\hline Spent Nuclear Fuel Project & & & & \multicolumn{2}{|c|}{ Date $01 / 25 / 96$} \\
\hline \multirow{2}{*}{\multicolumn{4}{|c|}{$\begin{array}{l}\text { Project Title/Work Order } \\
\text { Fuel Sorting Issue Resolution }\end{array}$}} & \multicolumn{2}{|c|}{ EDT No. 612993} \\
\hline & & & & \multicolumn{2}{|c|}{ ECN No. $\quad \mathrm{N} / \mathrm{A}$} \\
\hline Name & MSIN & $\begin{array}{l}\text { Text } \\
\text { With All } \\
\text { Attach. }\end{array}$ & Text Only & $\begin{array}{l}\text { Attach./ } \\
\text { Appendix } \\
\text { Only }\end{array}$ & $\begin{array}{c}\text { EDT/ECN } \\
\text { Only }\end{array}$ \\
\hline $\begin{array}{l}\text { D. S. Takasumi } \\
\text { C. A. Thompson } \\
\text { G. S. Voyles } \\
\text { J. C. Wiborg } \\
\text { M. J. Wiemers } \\
\text { M. E. Witherspoon } \\
\text { J. C. Womack } \\
\text { SNF Project File }\end{array}$ & $\begin{array}{l}X 3-85 \\
\text { R3-85 } \\
X 3-85 \\
\text { R3-86 } \\
\text { X3-85 } \\
\text { R3-85 } \\
\text { R3-86 } \\
\text { R3-11 }\end{array}$ & $\begin{array}{l}\text { EDT } \\
X \\
X \\
X \\
X \\
X \\
X \\
X\end{array}$ & nd Item 1 & only & \\
\hline
\end{tabular}

